\title{
Supercritical extraction of decellularized extracellular matrix from porcine adipose tissue as regeneration therapeutics
}

\author{
Seungwon Chung, $\mathrm{MS}^{1} \mathbb{1}$, Hana Kwon, $\mathrm{MS}^{2} \mathbb{1}$, Namsoo Peter Kim, $\mathrm{PhD}^{1,2}$ (iD) \\ 'Department of Metallurgical Materials and Biomedical Engineering, The University of Texas at El Paso, El Paso, TX. United States \\ ${ }^{2}$ Center for Printing Materials Certification, The University of Texas at EI Paso, El Paso, TX, United States
}

Background: Extracellular matrix (ECM) has been broadly applied and shown great promise in medical applications. ECM products should be used after decellularization and purification. Supercritical carbon dioxide treatment is of particular interest for purifying ECM due to its medical availability and rapid process speed. However, it is not fully researched for treatment of biomaterials for tissue engineering. Therefore, we investigated the optimal conditions of supercritical carbon dioxide processing at different extracting parameters in porcine adipose tissue.

Objective: We aimed to identify the optimal supercritical extracting conditions to produce non-cytotoxic and sterile decellularized extracellular matrix (DE-ECM) for regeneration therapeutics.

Methods: The three-day dual treatment including enzymatic decellularization and supercritical fluid extraction of pork adipose tissue was performed. Two protocols using different extracting parameters were applied to evaluate the influence of extracting pressure and temperature on the extraction yield, DNA concentration, and remaining collagen in product.

Results: Yield rate increased when high temperature or pressure was applied and pre-enzyme treatment had higher yield rate percent than pre-supercritical processing. Nearly $90 \%$ DNA was removed from the pre-enzyme sample when extracted at $3.04 \times 10^{7}$ $\mathrm{Pa}$ and $30^{\circ} \mathrm{C} \pm 5^{\circ} \mathrm{C}$. The pre-enzyme process had efficient extracting ability at each temperature and pressure and the remaining collagen steadily decreased with increase in extracting pressure and temperature. At the lowest temperature $\left(20^{\circ} \mathrm{C} \pm 5^{\circ} \mathrm{C}\right)$ and pressure $\left(1.01 \times 10^{7} \mathrm{~Pa}\right)$, remaining collagen was $75.74 \% \pm 1.83 \%$. Supercritical extraction technology can produce DE-ECM eliminating DNA content efficiently and the remaining proper collagen amount successfully.

Conclusion: This study evaluated the feasibility of utilizing supercritical extraction technology in bio-materials and was proven to be is successful. Through controlling the extracting pressure and temperature, this technology has a potential for DE-ECM mass production, which can be useful as tissue regeneration therapeutics as well new drug delivery paradigm.

Keywords: enzyme decellularization; extracellular matrix; regeneration therapeutics; supercritical extraction process

\section{Introduction}

Tissue engineering (TE) has been proposed for in vitro production of artificial tissues and organs and related issues have attracted attention in the medical field. Currently, various biopolymers and materials for regeneration therapy are being researched. However, there are side effects such as in vivo tissue damage due to $\mathrm{pH}$ decrease in the implanted site and worsen-

Received November 29, 2019; Revised December 19, 2019; Accepted December 22, 2019

Corresponding author: Namsoo Peter Kim

E-mail: nkim@utep.edu

This is an Open Access article distributed under the terms of the Creative Commons Attribution Non-Commercial License (http://creativecommons.org/licenses/by-nc/4.0), which permits unrestricted non-commercial use, distribution, and reproduction in any medium, provided the original work is properly cited.

Copyright (c) 2019 Korean Society of Korean Cosmetic Surgery and Medicine (KSKCS \& KCCS). 
ing biocompatibility with time. Therefore, natural materials with high degree of biocompatibility as well as the ability to direct cellular proliferation and constructive tissue remodeling have attracted attention from researchers and showed great promise in medical applications [1,2]. Especially, biological scaffold including extracellular matrix (ECM) has been broadly applied in medical field [3-6]. The ECM is a complex matrix surrounded by cells and take structural and biochemical supporting functions from bioactive ingredients such as collagen, elastin, glycosaminoglycans (GAGs), growth factors, and cytokine [7,8]. However, traditional decellularization method generally use chemical detergents that are cytotoxic and can damage ECM and has disadvantages such as high cost and being time-consuming [912]. As shown in Table 1, most decellularization methods can transform the 3-dimensional biostructure of tissues related to mechanical properties; also, the chemical detergents and acids can remain inside the tissue after processing and cause substantial adverse immune effects [13-22].

In this study, two decellularizing and purifying protocols were used to produce medically available decellularized extracellular matrix (DE-ECM). Pork adipose tissue was used because it is an abundant source of useful particles such as collagen, peptides, and cytokines [23,24]. Decellularization was performed with enzyme solutions that separate proteins and eliminate lipid or cellular contents [25-27]. To overcome time-consuming limitations of chemical decellularization, the supercritical extraction by carbon dioxide $\left(\mathrm{SC}-\mathrm{CO}_{2}\right)$ was applied as additional purification process [28]. Supercritical fluid is achieved when the substance is above critical point and cannot be defined as liquid or gas. It has particular properties-selectivity, expeditiousness, and high degree of dissolution ability_-because it has intermediate properties of viscosity and density of gas and liquid. Using carbon dioxide as the main solvent enhances extraction efficiency since it is non-corrosive, non-flammable, and nontoxic and has short process time and high efficiency. SC- $\mathrm{CO}_{2}$ has variety of application in foods and biomaterial because the pressure and temperature at supercritical state have a moderate value [2932]. This study focuses on the medically available synthesis of bi compatible DE-ECM applying SC- $\mathrm{CO}_{2}$ and investigates the optimal extracting conditions for elimination of DNA content and useless components.

\section{Materials and methods}

The produced DE-ECM was decellularized with enzymatic solution and supercritical extracted with $\mathrm{CO}_{2}\left(\mathrm{SC}-\mathrm{CO}_{2}\right)$. The experimental processes are summarized in Fig. 1. In brief, the three-day, cost-effective, and non-toxic procedure involved enzymatic decellularization and supercritical fluid extraction treatment. Two types of treatment protocols were followed. According to the first treatment method, the supercritical extraction was carried out after enzyme decellularization process (pre-enzyme treatment). According to the second treatment, the enzyme process was carried out after supercritical extraction (pre-supercritical treatment). Different extracting parameters were applied for these experiments; extractions were carried out at different pressures and temperature to evaluate the influence of pressure and temperature on the extraction yield, DNA concentration, and remaining collagen amount. All the decreased weight data were recorded.

Table 1. Summary of decellularization agents and technique for producing decellularized extracellular matrix tissue

\begin{tabular}{|c|c|c|c|}
\hline Agent/technique & Mechanism & Effect & Reference \\
\hline Acids and base & $\begin{array}{l}\text { Solubilize cytoplasmic components of cells and } \\
\text { tend to denature proteins. }\end{array}$ & Decrease collagen amount and GAG. & {$[15,16]$} \\
\hline $\begin{array}{l}\text { Hypotonic and hypertonic } \\
\text { solutions }\end{array}$ & $\begin{array}{l}\text { Occur Cell lysis by osmotic shock and disrupt } \\
\text { DNA-protein interactions. }\end{array}$ & Non-effective in removing cellular residue. & {$[17]$} \\
\hline Tributyl phosphate & $\begin{array}{l}\text { Form stable complexes with metals and disrupt } \\
\text { protein-protein interactions. }\end{array}$ & $\begin{array}{l}\text { Mixed results with efficacy dependent on tissue, } \\
\text { dense tissues lost collagen. }\end{array}$ & {$[18]$} \\
\hline Freezing & Intracellular ice crystals disrupt cell membrane. & $\begin{array}{l}\text { Ice crystal formation disrupts or fracture in } \\
\text { product. }\end{array}$ & {$[20]$} \\
\hline Electroporation & Pulsed electrical fields disrupt cell membranes. & Electrical field oscillation disrupts ECM structure. & {$[21]$} \\
\hline Agitation & Lyse cells and facilitate chemical exposure. & Aggressive agitation or sonication damages ECM. & {$[21]$} \\
\hline Perfusion & $\begin{array}{l}\text { Facilitate chemical exposure and removal of } \\
\text { cellular material. }\end{array}$ & Pressure associated with perfusion disrupt ECM. & {$[22]$} \\
\hline
\end{tabular}

GAG, glycosaminoglycans; ECM, extracellular matrix. 


\section{Raw adipose tissue preparation}

Pork adipose tissue was used to produce DE-ECM. The raw pork was obtained from a local grocery store and kept in the freezer to avoid degradation. The comminution of the raw adipose tissue was harvested using an electric grinder and each tissue was cut into small pieces of different thickness ( $\mathrm{Tl}, 1.9 \times 10^{-3}$ $\mathrm{m} ; \mathrm{T} 2,5.7 \times 10^{-3} \mathrm{~m}$; and $\left.\mathrm{T} 3,9.5 \times 10^{-3} \mathrm{~m}\right)$. The raw adipose tissues prepared were of identical volume, $3.8 \times 10^{-7} \mathrm{~m}^{3}$. It was possible to control volume of all the tissues.

\section{$\mathrm{SC}-\mathrm{CO}_{2}$ treatment}

The supercritical extractions were carried out to remove DNA components and purify by non-toxic and non-destructive

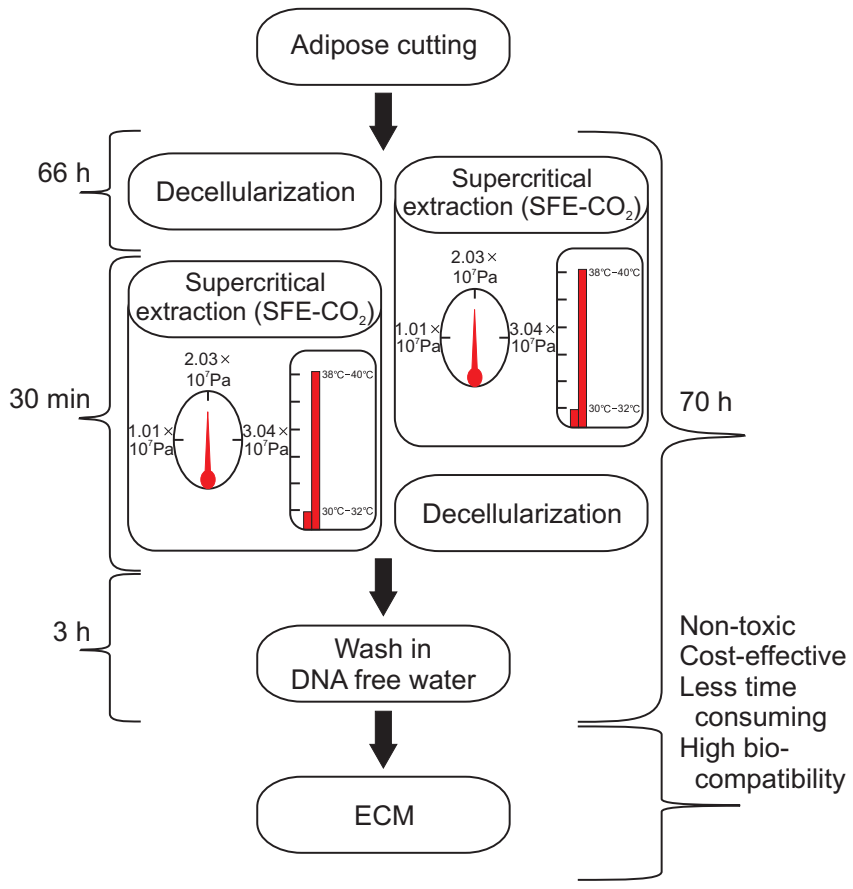

Fig. 1. Scheme of the decellularization process and supercritical fluid treatment procedure. SFE- $\mathrm{CO}_{2}$, supercritical- $\mathrm{CO}_{2}$ fluid extraction; ECM, extracellular matrix. way by the apparatus described in Fig. 2 (OCO-LABS, Redway, CA, USA). The extractor includes an extraction vessel with maximum operating pressure $5.07 \times 10^{7} \mathrm{~Pa}$. Pressure within the extraction vessel (described in Fig. 2C) was kept constant by monitoring via a gas gauge and the temperature was set by internal sensors. The extracted ingredients were collected in the flask (Fig. 2D) by depressurizing after 30 minutes. The extractions were conducted in 30 minute cycles to give enough time for the supercritical fluid to dissolve the target components. Carbon dioxide was utilized as the solvent material, which has medically available features. To eliminate the residual extracted ingredients on the surface, tissues were purified with deionized water during 180 minutes. Different extracting parameters were applied in order to compare extraction efficiency (temperature: $20^{\circ} \mathrm{C} \pm 5^{\circ} \mathrm{C}, 30^{\circ} \mathrm{C} \pm 5^{\circ} \mathrm{C}$, and $40^{\circ} \mathrm{C} \pm 5^{\circ} \mathrm{C}$; pressure: $1.01 \times 10^{7} \mathrm{~Pa}$, $2.03 \times 10^{7} \mathrm{~Pa}$, and $3.04 \times 10^{7} \mathrm{~Pa}$ ). The produced tissue mass was measured before and after the extraction as well. The experiments were conducted thrice in each condition to investigate the effect of extracting variables.

\section{Decellularization process (enzyme treatment)}

Decellularization was performed via the three-day protocol. The adipose tissues were subjected to chemical decellularization with enzymatic solutions and deionized water. The tissues were submerged into a 1:1 solution of $0.05 \%$ Trypsin-EDTA and $0.032 \mathrm{M}$ deoxycholic acid (Sigma-Aldrich, St. Louis, MO, USA). The adipose tissues were then thoroughly submerged in a 1:1 solution of $0.02 \%$ Trypsin and deoxycholic acid at $20^{\circ} \mathrm{C}$ and incubated overnight for 48 hours. This enzymatic digestive solution dissociates protein and adherent cells. The amount of solution used was five times the tissue mass. Subsequently, the tissues were rinsed with $30 \mathrm{ml}$ deionized water. Temperature and $\mathrm{pH}$ (approximately $\mathrm{pH}$ 7) were measured to determine whether other accidental chemical reactions occurred. Following a washing course in deionized water, the tissues were
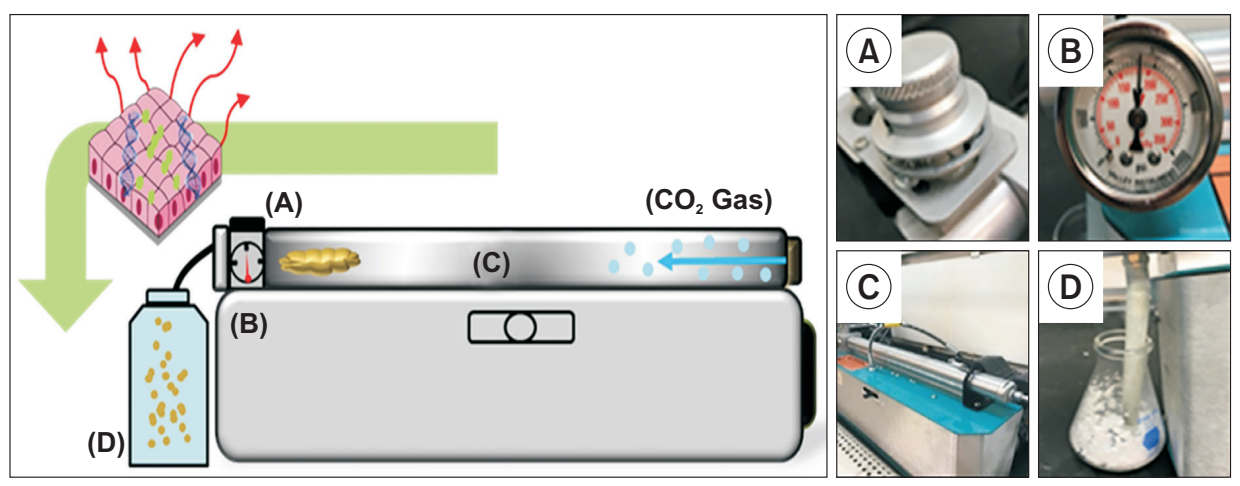

Fig. 2. Supercritical $\mathrm{CO}_{2}$ extraction system (OCO-LABS, Redway, CA, USA): (A) gas control valve; (B) gas gauge; (C) extracting chamber; (D) waste collecting flask. 
transferred into the solutions containing Triton X-100 (SigmaAldrich) and deionized water for six hours. The tissue was then put in deionized water to re-rinse for six hours. Finally, the adipose segments were mechanically compressed for dehydration and then stored at $4^{\circ} \mathrm{C}$.

\section{DNA assay}

To investigate the DNA concentration after treatment, Picogreen dsDNA assay (Invitrogen, Camarillo, CA, USA) was performed [33]. Since it is a colorimetric procedure, the test materials for analysis must be free from particulate materials such as cell debris and insoluble ECM fragments. To expose DNA contents, acid-pepsin digestion was applied to the tissues. They were submerged in $0.1 \mathrm{mg}$ pepsin/ml $0.5 \mathrm{M}$ acetic acid, which works as an enzyme for eliminating the terminal non-helical telopeptides to release the ingredients into solution. After preexperiment to prepare samples for evaluation, DNA concentration was measured by VERSA Max Tunable Microplate Reader (Molecular Devices Corp., San Jose, CA, USA).

\section{Sircol collagen assay}

The amount of remaining collagen after treatment was evaluated by assaying soluble collagen with a sircol collagen assay (SCA) kit (Biocolor Ltd., County Antrim, UK). Briefly, SCA is a colorimetric procedure therefore tissue were freed of cell debris and insoluble ECM fragments. The test samples (10 mg each) were homogenized in acetic acid with pepsin. Each sample was incubated at $4^{\circ} \mathrm{C}$ and separated into pellet and supernatant by centrifugation. Sircol dye reagent that binds to collagen was applied to each sample. After centrifugation, an alkaline reagent was added to the pellet. The absorbance was measured at 540 $\mathrm{nm}$ wavelength on a microplate reader.

\section{Results}

A non-toxic, cost-effective, and short DE-ECM processing methodology including supercritical extraction and enzymatic decellularization was established. Adipose tissues were treated with different process protocols (pre-enzyme or pre-supercritical process). After the completed processes, the white colored matrix with significantly decreased mass was collected (Fig. 3). Macroscopically, the raw adipose tissue size was different according to its thickness because of mechanical compression, but the produced DE-ECM had a similar appearance with it being whiter than the raw tissue after the entire processes.

\section{Yield rate}

The yield rate of DE-ECM with different extracting parameters was compared (Table 2). Adipose tissues with three different thicknesses were processed via the pre-enzyme or pre-supercritical process at three different pressures and two different temperatures. The tissue weight before and after processing was measured. It was found that yield rate depends on the extracting temperature and pressure. Fig. 4 shows the influence of extracting pressure and temperature on yield rate. The yield rates at $40^{\circ} \mathrm{C} \pm 5^{\circ} \mathrm{C}$ using different protocols and at different pressures were as follows: pre-enzyme process at $1.01 \times 10^{7} \mathrm{~Pa}: 25.13 \% \pm 4.02 \%, 2.03 \times 10^{7} \mathrm{~Pa}: 40.87 \% \pm 3.09 \%$, and $3.04 \times 10^{7} \mathrm{~Pa}: 45.62 \% \pm 3.75 \%$; pre-supercritical process at $1.01 \times 10^{7}$ Pa: $14.40 \% \pm 3.54 \%, 2.03 \times 10^{7} \mathrm{~Pa}: 19.31 \% \pm 5.95 \%$, and $3.04 \times 10^{7}$ Pa: $21.47 \% \pm 5.58 \%$. Similarly, the yield rates at $30^{\circ} \mathrm{C} \pm 5^{\circ} \mathrm{C}$ were: pre-enzyme process at $1.01 \times 10^{7} \mathrm{~Pa}: 18.34 \% \pm 7.46 \%, 2.03 \times 10^{7}$ Pa: $26.58 \% \pm 4.35 \%$, and $3.04 \times 10^{7} \mathrm{~Pa}: 34.04 \% \pm 4.04 \%$; presupercritical process at $1.01 \times 10^{7} \mathrm{~Pa}: 4.85 \% \pm 3.04 \%, 2.03 \times 10^{7}$ Pa: $15.49 \% \pm 2.47 \%$, and $3.04 \times 10^{7} \mathrm{~Pa}: 21.74 \% \pm 8.12 \%$. Yield rate increased when high temperature or pressure was applied. Furthermore, pre-enzyme treatment had higher processed DEECM yield rate percent than that of pre-supercritical treatment. The maximum yield rate observed was nearly $46 \%$ at $3.04 \times 10^{7}$ Pa pressure and $40^{\circ} \mathrm{C} \pm 5^{\circ} \mathrm{C}$ temperature using the pre-enzyme process.
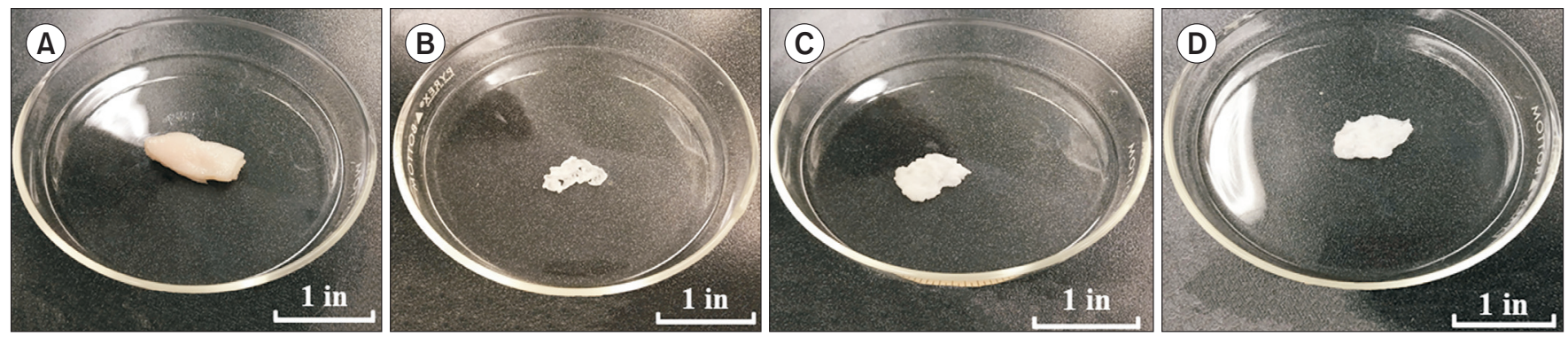

Fig. 3. Images of tissues before and after treatments. (A) Raw adipose tissue; (B) $1.90 \times 10^{-3} \mathrm{~m}$ produced decellularized extracellular matrix (DEECM) tissue; (C) $5.70 \times 10^{-3} \mathrm{~m}$ produced DE-ECM tissue; (D) $9.50 \times 10^{-3} \mathrm{~m}$ produced DE-ECM tissue. 
Table 2. Extraction yield of decellularized extracellular matrix product with different extraction condition

\begin{tabular}{|c|c|c|c|c|c|}
\hline Adipose tissue & Process & Pressure $\left(\times 10^{7} \mathrm{~Pa}\right)$ & Temperature $\left( \pm 5^{\circ} \mathrm{C}\right)$ & Weight of original mass (g) & Weight of product (g) \\
\hline \multirow[t]{12}{*}{1} & $\mathrm{PE}$ & 1.01 & 30 & 0.21 & 0.17 \\
\hline & & & 40 & 0.20 & 0.16 \\
\hline & & 2.03 & 30 & 0.22 & 0.15 \\
\hline & & & 40 & 0.25 & 0.15 \\
\hline & & 3.04 & 30 & 0.23 & 0.15 \\
\hline & & & 40 & 0.20 & 0.09 \\
\hline & PS & 1.01 & 30 & 0.15 & 0.15 \\
\hline & & & 40 & 0.24 & 0.20 \\
\hline & & 2.03 & 30 & 0.24 & 0.19 \\
\hline & & & 40 & 0.19 & 0.14 \\
\hline & & 3.04 & 30 & 0.20 & 0.14 \\
\hline & & & 40 & 0.17 & 0.12 \\
\hline \multirow[t]{12}{*}{2} & $\mathrm{PE}$ & 1.01 & 30 & 0.47 & 0.37 \\
\hline & & & 40 & 0.45 & 0.34 \\
\hline & & 2.03 & 30 & 0.61 & 0.47 \\
\hline & & & 40 & 0.49 & 0.29 \\
\hline & & 3.04 & 30 & 0.52 & 0.33 \\
\hline & & & 40 & 0.64 & 0.38 \\
\hline & PS & 1.01 & 30 & 0.44 & 0.35 \\
\hline & & & 40 & 0.43 & 0.38 \\
\hline & & 2.03 & 30 & 0.46 & 0.39 \\
\hline & & & 40 & 0.53 & 0.46 \\
\hline & & 3.04 & 30 & 0.45 & 0.36 \\
\hline & & & 40 & 0.42 & 0.35 \\
\hline \multirow[t]{12}{*}{3} & $\mathrm{PE}$ & 1.01 & 30 & 0.62 & 0.56 \\
\hline & & & 40 & 0.62 & 0.44 \\
\hline & & 2.03 & 30 & 0.60 & 0.42 \\
\hline & & & 40 & 0.62 & 0.35 \\
\hline & & 3.04 & 30 & 0.70 & 0.48 \\
\hline & & & 40 & 0.60 & 0.35 \\
\hline & PS & 1.01 & 30 & 0.67 & 0.64 \\
\hline & & & 40 & 0.70 & 0.60 \\
\hline & & 2.03 & 30 & 0.89 & 0.80 \\
\hline & & & 40 & 0.62 & 0.51 \\
\hline & & 3.04 & 30 & 0.78 & 0.66 \\
\hline & & & 40 & 0.67 & 0.55 \\
\hline
\end{tabular}

Adipose tissue 1: thickness $1.9 \times 10^{-3} \mathrm{~m}$, Adipose tissue 2: thickness $5.7 \times 10^{-3} \mathrm{~m}$, Adipose tissue 3: thickness $9.5 \times 10^{-3} \mathrm{~m}$. PE, pre-enzyme process; PS, pre-supercritical process.

\section{DNA assay}

The DNA content in DE-ECM tissues was compared with that of native adipose tissue (measured average DNA concentration: $0.065 \mu \mathrm{g} / \mathrm{ml}$ ). Fig. 5 shows the concentration of remaining DNA after decellularization and supercritical extraction at different temperatures and pressures (DNA concentration of DE-ECM tissues produced using pre-enzyme process at $40^{\circ} \mathrm{C} \pm 5^{\circ} \mathrm{C}-1.01 \times 10^{7} \mathrm{~Pa}: 49.23 \% \pm 3.48 \%, 2.03 \times 10^{7} \mathrm{~Pa}$ : $24.62 \% \pm 4.35 \%$, and $3.04 \times 10^{7} \mathrm{~Pa}: 10.77 \% \pm 3.43 \%$; DNA concen- tration of DE-ECM tissues using produced pre-supercritical process at $40^{\circ} \mathrm{C} \pm 5^{\circ} \mathrm{C}-1.01 \times 10^{7} \mathrm{~Pa}: 61.54 \% \pm 1.10 \%, 2.03 \times 10^{7}$ Pa: $56.92 \% \pm 2.39 \%$, and $3.04 \times 10^{7}$ Pa: $27.69 \% \pm 1.31 \%$; DNA concentration of DE-ECM tissues produced using pre-enzyme process at $30^{\circ} \mathrm{C} \pm 5^{\circ} \mathrm{C}-1.01 \times 10^{7} \mathrm{~Pa}: 24.62 \% \pm 5.52 \%, 2.03 \times 10^{7} \mathrm{~Pa}$ : $18.46 \% \pm 3.36 \%$, and $3.04 \times 10^{7} \mathrm{~Pa}: 9.23 \% \pm 0.38 \%$; DNA concentration of DE-ECM tissues using produced pre-supercritical process at $30^{\circ} \mathrm{C} \pm 5^{\circ} \mathrm{C}-1.01 \times 10^{7} \mathrm{~Pa}: 38.46 \% \pm 6.16 \%, 2.03 \times 10^{7} \mathrm{~Pa}$ : $30.77 \% \pm 10.22 \%$, and $\left.3.04 \times 10^{7} \mathrm{~Pa}: 21.54 \% \pm 3.18 \%\right)$. DNA concen- 

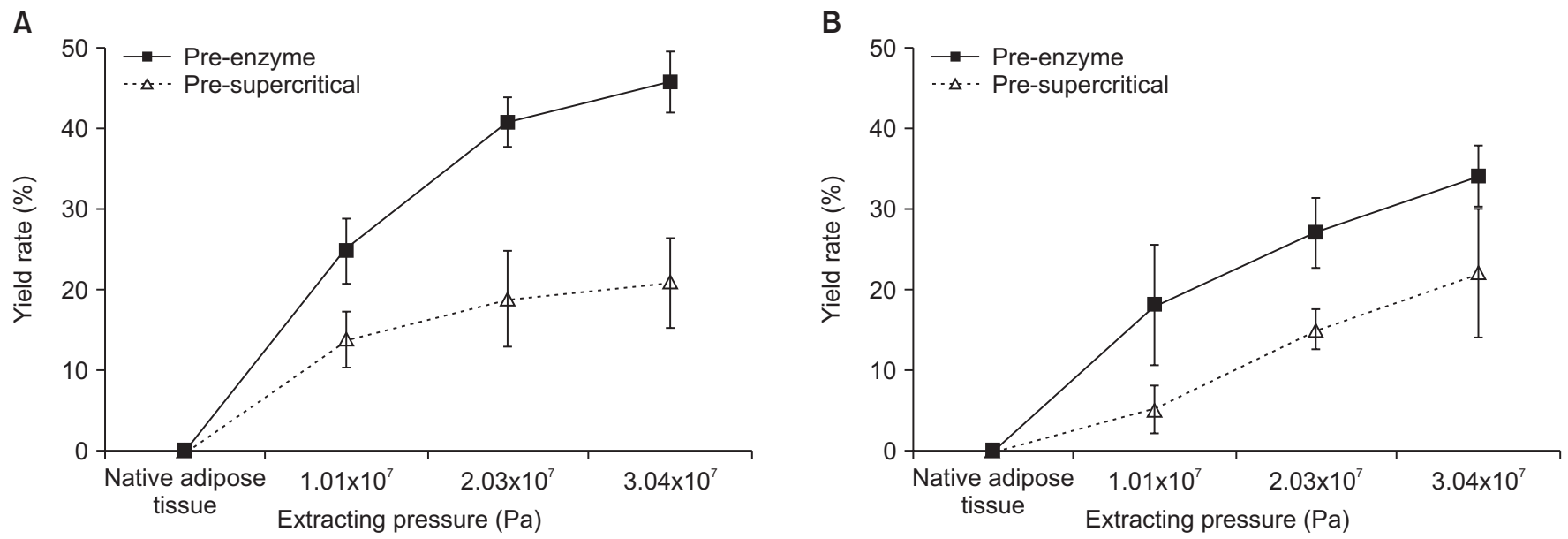

Fig. 4. Average yield rate (\%) following different extracting pressure $\left(1.01 \times 10^{7} \mathrm{~Pa}, 2.03 \times 10^{7} \mathrm{~Pa}\right.$, and $\left.3.04 \times 10^{7} \mathrm{~Pa}\right)$ for different treatment process (pre-enzyme process and pre-supercritical process). (A) Extraction temperature at $40^{\circ} \mathrm{C} \pm 5^{\circ} \mathrm{C}$; (B) Extraction temperature at $30^{\circ} \mathrm{C} \pm 5^{\circ} \mathrm{C}$.
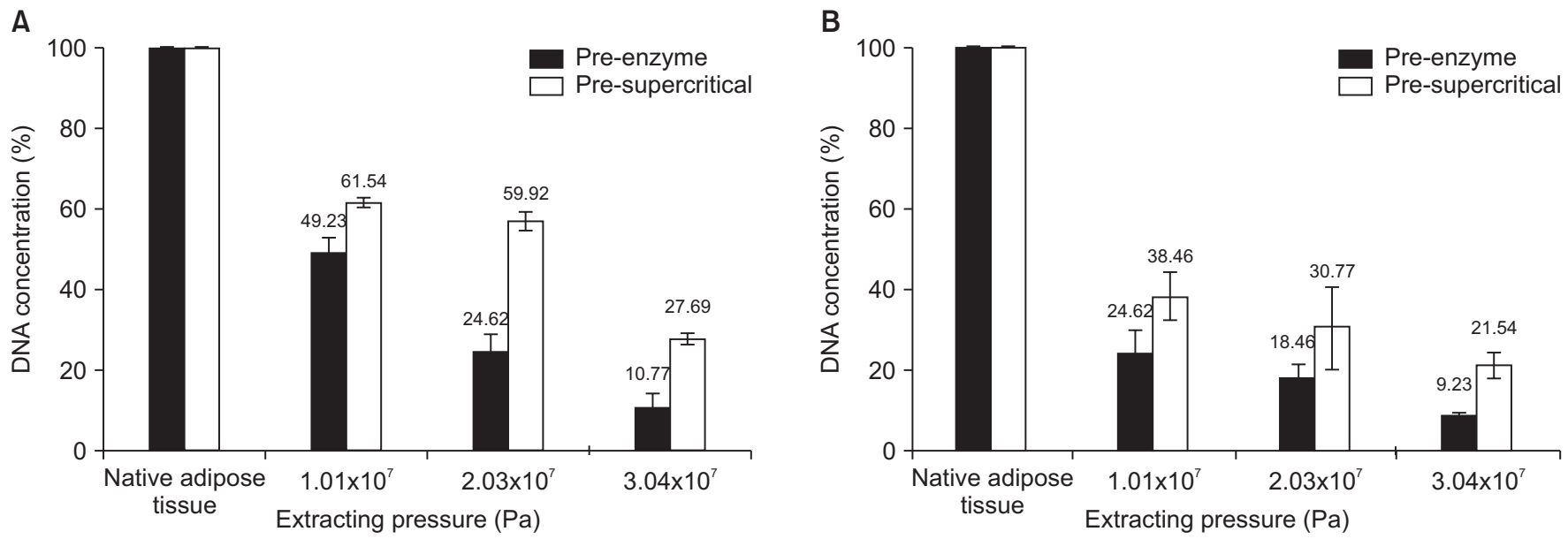

Fig. 5. Effect of extracting pressure and temperature on remaining DNA concentration after treatment. Amount of remaining DNA concentration was compared between raw adipose tissue prior process with produced extracellular matrix (ECM) tissue. The adipose samples were subjected to various extracting pressure $\left(1.01 \times 10^{7} \mathrm{~Pa}, 2.03 \times 10^{7} \mathrm{~Pa}\right.$, and $\left.3.04 \times 10^{7} \mathrm{~Pa}\right)$, extracting temperature and different processing methods. (A) Decellularized extracellular matrix (DE-ECM) samples extracted at $40^{\circ} \mathrm{C} \pm 5^{\circ} \mathrm{C}$. (B) DE-ECM samples extracted at $30^{\circ} \mathrm{C} \pm 5^{\circ} \mathrm{C}$.

tration of DE-ECM tissues extracted using pre-enzyme process at $3.04 \times 10^{7} \mathrm{~Pa}$ and $30^{\circ} \mathrm{C} \pm 5^{\circ} \mathrm{C}$ was the lowest, with nearly $90 \%$ DNA being removed. This result indicates that the different kinds of ingredients, which contain different value of DNA contents, are extracted because of solubility difference.

\section{Collagen assay}

The influence of temperature and pressure on the collagen concentration is presented in Fig. 6. The collagen amount in DE-ECM tissues were compared to those in original native adipose tissue (measured collagen content: $\sim 0.90 \pm 0.03 \mu \mathrm{g} / \mathrm{ml}$ ). Fig. 6 indicates that collagen amount steadily decreased with increase in extracting pressure from $1.01 \times 10^{7}$ to $3.04 \times 10^{7} \mathrm{~Pa}$. Moreover, DE-ECM tissues produced at $20^{\circ} \mathrm{C} \pm 5^{\circ} \mathrm{C}$ had more col- lagen than the tissues processed at $30^{\circ} \mathrm{C} \pm 5^{\circ} \mathrm{C}$ and $40^{\circ} \mathrm{C} \pm 5^{\circ} \mathrm{C}$. At $40^{\circ} \mathrm{C} \pm 5^{\circ} \mathrm{C}$, the collagen content of DE-ECM were $24.88 \% \pm 2.44 \%$, $14.08 \% \pm 2.10 \%$, and $8.11 \% \pm 6.87 \%$ at $1.01 \times 10^{7} \mathrm{~Pa}, 2.03 \times 10^{7}$ $\mathrm{Pa}$, and $3.04 \times 10^{7} \mathrm{~Pa}$, respectively. At $30^{\circ} \mathrm{C} \pm 5^{\circ} \mathrm{C}$, they were $33.97 \% \pm 0.67 \%, 22.59 \% \pm 0.79 \%$, and $17.72 \% \pm 4.86 \%$ at $1.01 \times 10^{7}$, $2.03 \times 10^{7}$, and $3.04 \times 10^{7} \mathrm{~Pa}$, respectively. Similarly, at $20^{\circ} \mathrm{C} \pm 5^{\circ} \mathrm{C}$, they were $75.74 \% \pm 1.83 \%, 43.17 \% \pm 3.57 \%$, and $32.11 \% \pm 4.78 \%$ at $1.01 \times 10^{7} \mathrm{~Pa}, 2.03 \times 10^{7} \mathrm{~Pa}$, and $3.04 \times 10^{7} \mathrm{~Pa}$, respectively.

\section{Discussion}

The purpose of this study was to produce biocompatible DE-ECM by a cost-effective, short, and non-toxic process. Supercritical fluid extraction with carbon dioxide $\left(\mathrm{SC}-\mathrm{CO}_{2}\right)$ and 


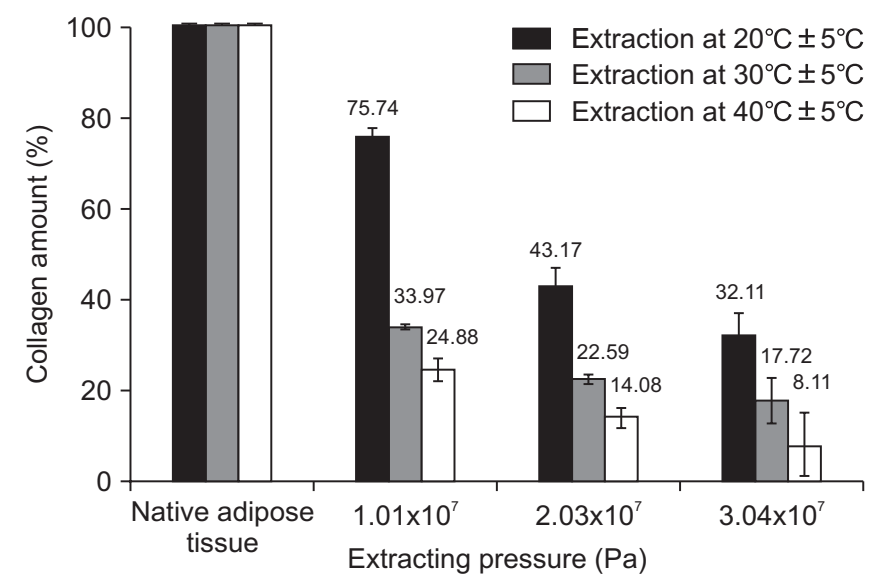

Fig. 6. Remaining collagen concentration in produced decellularized extracellular matrix (DE-ECM) tissues. DE-ECM tissues were processed with pre-enzyme process, but different extracting temperature $\left(20^{\circ} \mathrm{C} \pm 5^{\circ} \mathrm{C}, 30^{\circ} \mathrm{C} \pm 5^{\circ} \mathrm{C}\right.$, and $\left.40^{\circ} \mathrm{C} \pm 5^{\circ} \mathrm{C}\right)$ and different pressure $\left(1.01 \times 10^{7} \mathrm{~Pa}, 2.03 \times 10^{7} \mathrm{~Pa}\right.$, and $\left.3.04 \times 10^{7} \mathrm{~Pa}\right)$ was applied.

decellularization with enzymatic solutions were applied to treat DE-ECM. The combination of SC- $\mathrm{CO}_{2}$ and enzyme treatment produced DE-ECM samples in 70 hours cost-effectively and satisfactorily eliminated DNA. To increase solvent solubility, different experiment parameters such as extracting pressure and temperature were investigated by increasing the solvent density $[34,35]$. However, in a different aspect, temperature had a severe effect on the collagen composition of DE-ECM since collagen is vulnerable at high temperature [36,37]. DNA analysis showed that extraction using pre-enzyme process at $30^{\circ} \mathrm{C} \pm 5^{\circ} \mathrm{C}$ and $3.04 \times 10^{7} \mathrm{~Pa}$ was the optimal condition to decrease DNA concentration, that is, DNA concentration decreased from 0.065 $\mu \mathrm{g} / \mathrm{ml}$ of original adipose tissue to $0.006 \mu \mathrm{g} / \mathrm{ml}$ of produced DE-ECM. Collagen is a critical element in pharmaceutical and biomedical industries and has an important role in tissue and organ formation due to ultimate biocompatibility with the immune system. The collagen analysis result shows that DEECM produced at optimal extraction conditions using the preenzyme process had $0.16 \mu \mathrm{g} / \mathrm{ml}$ collagen; $17.72 \%$. Thus, high pressure and low temperature are the effective variables to produce biocompatible DE-ECM. Application of supercritical fluid extraction and enzyme decellularization process proves that cost-effective, non-toxic, and less time-consuming production of medically available DE-ECM is possible without using any unnecessary chemicals that damages the biostructure. Moreover, controlling pressure and temperature provides optimal biocompatibility and has a potential usage of supercritical fluid extraction in DE-ECM mass production, as it is a rapid process. This study evaluated the feasibility of utilizing supercritical extraction technology in biomaterials and it was proven successful. Moreover, medically available DE-ECM can be utilized in tissue regeneration therapeutics including medical pad with drugs as well as new drug delivery paradigm.

\section{Conflicts of interest}

The authors have nothing to disclose.

\section{References}

1. Badylak SF. Xenogeneic extracellular matrix as a scaffold for tissue reconstruction. Transpl Immunol 2004;12:367-77.

2. Vorotnikova E, McIntosh D, Dewilde A, Zhang J, Reing JE, Zhang L, et al. Extracellular matrix-derived products modulate endothelial and progenitor cell migration and proliferation in vitro and stimulate regenerative healing in vivo. Matrix Biol 2010;29:690-700.

3. Guler S, Aslan B, Hosseinian P, Aydin HM. Supercritical carbon dioxide-assisted decellularization of aorta and cornea. Tissue Eng Part C Methods 2017;23:540-7.

4. Bible E, Dell'Acqua F, Solanky B, Balducci A, Crapo PM, Badylak SF, et al. Non-invasive imaging of transplanted human neural stem cells and ECM scaffold remodeling in the strokedamaged rat brain by (19)F- and diffusion-MRI. Biomaterials 2012;33:2858-71.

5. Ott HC, Matthiesen TS, Goh SK, Black LD, Kren SM, Netoff TI, et al. Perfusion-decellularized matrix: using nature's platform to engineer a bioartificial heart. Nat Med 2008;14:213-21.

6. Song JJ, Ott HC. Organ engineering based on decellularized matrix scaffolds. Trends Mol Med 2011;17:424-32.

7. Choi YC, Choi JS, Kim BS, Kim JD, Yoon HI, Cho YW. Decellularized extracellular matrix derived from porcine adipose tissue as a xenogeneic biomaterial for tissue engineering. Tissue Eng Part C Methods 2012;18:866-76.

8. Badylak SF. The extracellular matrix as a scaffold for tissue reconstruction. Semin Cell Dev Biol 2002;13:377-83.

9. Gholipourmalekabadi M, Mozafari M, Salehi M, Seifalian A, Bandehpour M, Ghanbarian H, et al. Development of a cost-effective and simple protocol for decellularization and preservation of human amniotic membrane as a soft tissue replacement and delivery system for bone marrow stromal cells. Adv Healthc Mater 2015;4:918-26.

10. Jungebluth P, Go T, Asnaghi A, Bellini S, Martorell J, Calore C, et al. Structural and morphologic evaluation of a novel detergent-enzymatic tissue-engineered tracheal tubular matrix. J 
Thorac Cardiovasc Surg 2009;138:586-93; discussion 592-3.

11. Haykal S, Soleas JP, Salna M, Hofer SO, Waddell TK. Evaluation of the structural integrity and extracellular matrix components of tracheal allografts following cyclical decellularization techniques: comparison of three protocols. Tissue Eng Part C Methods 2012;18:614-23.

12. Keane TJ, Swinehart IT, Badylak SF. Methods of tissue decellularization used for preparation of biologic scaffolds and in vivo relevance. Methods 2015;84:25-34.

13. Prasertsung I, Kanokpanont S, Bunaprasert T, Thanakit V, Damrongsakkul S. Development of acellular dermis from porcine skin using periodic pressurized technique. J Biomed Mater Res B Appl Biomater 2008;85:210-9.

14. Crapo PM, Gilbert TW, Badylak SF. An overview of tissue and whole organ decellularization processes. Biomaterials 2011;32:3233-43.

15. Dong X, Wei X, Yi W, Gu C, Kang X, Liu Y, et al. RGD-modified acellular bovine pericardium as a bioprosthetic scaffold for tissue engineering. J Mater Sci Mater Med 2009;20:2327-36.

16. Reing JE, Brown BN, Daly KA, Freund JM, Gilbert TW, Hsiong SX, et al. The effects of processing methods upon mechanical and biologic properties of porcine dermal extracellular matrix scaffolds. Biomaterials 2010;31:8626-33.

17. Meyer SR, Chiu B, Churchill TA, Zhu L, Lakey JR, Ross DB. Comparison of aortic valve allograft decellularization techniques in the rat. J Biomed Mater Res A 2006;79:254-62.

18. Deeken CR, White AK, Bachman SL, Ramshaw BJ, Cleveland DS, Loy TS, et al. Method of preparing a decellularized porcine tendon using tributyl phosphate. J Biomed Mater Res B Appl Biomater 2011;96:199-206.

19. Rieder E, Kasimir MT, Silberhumer G, Seebacher G, Wolner E, Simon P, et al. Decellularization protocols of porcine heart valves differ importantly in efficiency of cell removal and susceptibility of the matrix to recellularization with human vascular cells. J Thorac Cardiovasc Surg 2004;127:399-405.

20. Hopkinson A, Shanmuganathan VA, Yeung AM, Gray T, Lowe J, Dua HS, et al. Optimisation of amniotic membrane (AM) denuding for tissue engineering. Acta Ophthalmol 2008. doi: 10.1111/j.1755-3768.2008.5436.x.

21. Phillips M, Maor E, Rubinsky B. Nonthermal irreversible electroporation for tissue decellularization. J Biomech Eng 2010;132:091003.

22. Wainwright JM, Czajka CA, Patel UB, Freytes DO, Tobita K, Gilbert TW, et al. Preparation of cardiac extracellular matrix from an intact porcine heart. Tissue Eng Part C Methods 2010;16:525-32.
23. Uriel S, Huang JJ, Moya ML, Francis ME, Wang R, Chang SY, et al. The role of adipose protein derived hydrogels in adipogenesis. Biomaterials 2008;29:3712-9.

24. Flynn LE. The use of decellularized adipose tissue to provide an inductive microenvironment for the adipogenic differentiation of human adipose-derived stem cells. Biomaterials 2010;31:4715-24.

25. Cho D, Chung S, Eo J, Kim NP. Super-critical- $\mathrm{CO}_{2}$ de-ECM process. MRS Adv 2018;3:2391-7.

26. Gilbert TW, Sellaro TL, Badylak SF. Decellularization of tissues and organs. Biomaterials 2006;27:3675-83.

27. Roosens A, Somers P, De Somer F, Carriel V, Van Nooten G, Cornelissen R. Impact of detergent-based decellularization methods on porcine tissues for heart valve engineering. Ann Biomed Eng 2016;44:2827-39.

28. Bamberger T, Erickson JC, Cooney CL, Kumar SK. Measurement and model prediction of solubilities of pure fatty acids, pure triglycerides, and mixtures of triglycerides in supercritical carbon dioxide. J Chem Eng Data 1988;33:327-33.

29. Ge Y, Ni Y, Yan H, Chen Y, Cai T. Optimization of the supercritical fluid extraction of natural vitamin $\mathrm{E}$ from wheat germ using response surface methodology. J Food Sci 2002;67:239-43.

30. Perrut M, Clavier JY, Poletto M, Reverchon E. Mathematical modeling of sunflower seed extraction by supercritical $\mathrm{CO}_{2}$. Ind Eng Chem Res 1997;36:430-5.

31. Lack E, Simándi B. 9.6 - Supercritical fluid extraction and fractionation from solid materials. Ind Chem Libr 2001;9:537-75.

32. Marsal A, Celma PJ, Cot JM, Cequier M. Supercritical $\mathrm{CO}_{2}$ extraction as a clean degreasing process in the leather industry. J Supercrit Fluids 2000;16:217-23.

33. Singer VL, Jones LJ, Yue ST, Haugland RP. Characterization of PicoGreen reagent and development of a fluorescence-based solution assay for double-stranded DNA quantitation. Anal Biochem 1997;249:228-38.

34. Wilshaw SP, Kearney JN, Fisher J, Ingham E. Production of an acellular amniotic membrane matrix for use in tissue engineering. Tissue Eng 2006;12:2117-29.

35. Roy BC, Goto M, Hirose T. Extraction of ginger oil with supercritical carbon dioxide: experiments and modeling. Ind Eng Chem Res 1996;35:607-12.

36. Vaquero EM, Beltrán S, Sanz MT. Extraction of fat from pigskin with supercritical carbon dioxide. J Supercrit Fluids 2006;37:142-50.

37. Jenkins CL, Raines RT. ChemInform abstract: insights on the conformational stability of collagen. ChemInform 2002;33. doi: 10.1002/chin.200218299. 